\title{
Korelacja wyników badań filtracji i wczesnej wytrzymałości mechanicznej zaczynów cementowych z dodatkiem mączki krzemionkowej
}

\author{
Correlation of filtration results and early mechanical strength of cement slurries \\ with the addition of silica
}

\author{
Marcin Kremieniewski \\ Instytut Nafty i Gazu - Państwowy Instytut Badawczy
}

\begin{abstract}
STRESZCZENIE: Uzyskanie szczelnego połączenia płaszcza cementowego zarówno z formacją skalną, jak i powierzchnią rur okładzinowych uzależnione jest od wielu parametrów projektowanego zaczynu cementowego. Jednym z bardziej istotnych parametrów jest filtracja zaczynu, której nadmierna wartość może powodować odfiltrowywanie wody w strefy chłonne, przez co zaczyn będzie wykazywał mniejszą przyczepność do powierzchni formacji skalnej, jak również do powierzchni rur okładzinowych. Dodatkowo nadmierna wartość filtracji może być przyczyną zakolmatowania strefy przyodwiertowej i w konsekwencji wydłużenia czasu niezbędnego do wywołania produkcji i zmniejszeniem wydajności odwiertu. Ponadto zbyt duże wartości filtratu w wyniku których wzrosną parametry reologiczne mogą być przyczyną rozszczelinowania złoża i utraty cyrkulacji, w związku z potrzebą użycia większych ciśnień tłoczenia zaczynu. Odpowiednia ilość wody zarobowej w zaczynie cementowym jest niezbędna do uzyskania wymaganego zgodnego z projektem cementowania czasu wiązania i osiągnięcia wymaganej wartości wytrzymałości na ściskanie. Parametry mechaniczne, głównie w początkowym okresie hydratacji zaczynu cementowego są niezwykle istotne z punktu widzenia przystąpienia do dalszych prac po cementowaniu oraz interpretacji uzyskanych wyników pomiarów stanu zacementowania. W przypadku uzyskania niskich wartości wczesnej wytrzymałości na ściskanie wyniki pomiarów geofizycznych mogą błędnie świadczyć o braku stwardniałego zaczynu cementowego w przestrzeni pierścieniowej. W związku z tym, że bardzo istotne jest utrzymanie wymaganych wartości filtracji płynnego zaczynu, jak również uzyskanie wymaganych optymalnych wartości wytrzymałości na ściskanie w niedługim czasie po wtłoczeniu zaczynu cementowego. W niniejszym artykule przedstawiono wyniki korelacji filtracji zaczynów i wczesnej wytrzymałości mechanicznej określonej za pomocą ultradźwiękowego analizatora cementu. W celu przeprowadzenia analizy korelacyjnej wartości filtracji i parametrów mechanicznych, wykonane zostały badania dla 8 receptur zaczynów, podzielonych na 2 grupy. W pierwszej grupie zaczynów zwiększano ilość dodatku mączki krzemionkowej przy zachowaniu stałego współczynnika wodno-cementowego natomiast w drugiej grupie zaczynów zwiększono również ilość wody w zaczynie. Dla tak opracowanych świeżych zaczynów wykonane zostały badania filtracji. Następnie zaczyny te zostały poddane badaniom narastania wczesnej wytrzymałości mechanicznej w ultradźwiękowym analizatorze cementu. Określano głównie wytrzymałość na ściskanie po 12, 24 oraz 48 godzinach od zarobienia zaczynu cementowego, a także czas rozpoczęcia budowania wytrzymałości mechanicznej oraz czas, po jakim stwardniały zaczyn uzyska wartość $3 \mathrm{MPa}$ oraz $4 \mathrm{MPa}$. Następnie uzyskane wyniki badań filtracji zaczynów oraz wartości wczesnej wytrzymałości na ściskanie zostały poddane analizie korelacyjnej na podstawie której określono zależność pomiędzy analizowanymi cechami.
\end{abstract}

Słowa kluczowe: filtracja zaczynu, zaczyn cementowy, wytrzymałość na ściskanie, korelacja, ultradźwiękowy analizator cementu.

ABSTRACT: Obtaining a tight connection of the cement sheath with both the rock formation and the surface of the casing depends on many parameters of the designed cement slurry. One of the most important parameters is the filtration of cement slurry, which excessive value may cause the filtration of water into the absorbing zones, so that the slurry will tend to detach from both the surface of the rock formation and also from the surface of the casing pipes. In addition, excessive filtration value can be the reason for clogging the zone near the well and, consequently, increase the time necessary to induce production and reduce the efficiency of the well. Too high values of the filtrate, as a result of which the rheological parameters increase, may cause cracking of the rock formation and loss of circulation, which will result from the necessity of using higher pressures. The correct amount of water in the cement slurry is necessary to obtain the required hardening time in accordance with the design and to achieve the required value of compressive strength.

Autor do korespondencji: M. Kremieniewski, e-mail: marcin.kremieniewski@inig.pl

Artykuł nadesłano do Redakcji 20.02.2019 r. Zatwierdzono do druku 6.06.2019 r. 
Mechanical parameters, mainly in the initial period of hydration of cement slurry are extremely important from the point of view of proceeding with further works after cementing and interpretation of the obtained results of cementing measurements. If low values of early compressive strength are obtained, the results of geophysical measurements may erroneously indicate a lack of hardened cement slurry in the annular space. As it is very important to obtain the required filtration values of the fresh slurry, as well as to obtain the required optimal compressive strengths shortly after the cement slurry placement, the paper presents the results of the correlation of cement slurry filtration and early mechanical strength determined by the Ultrasonic Cement Analyzer (UCA). In order to perform a correlation analysis of the filtration values and mechanical parameters, tests were carried out for 8 slurries, divided into two groups. In the first group of slurries the amount of the addition of silica flour was increased while maintaining a constant water-cement ratio, while in the second group of slurry the amount of water in the slurry was also increased. The filtration tests were carried out for fresh slurries. Then, these slurries were subjected to investigations of the expansion of early mechanical strength in an ultrasonic cement analyzer. The compression strength was determined mainly after 12, 24 and 48 hours from making a cement slurry as well as the start time of building mechanical strength and the time after which the hardened cement will obtain $3 \mathrm{MPa}$ and $4 \mathrm{MPa}$. Next, the obtained results of the filtration of slurries and values of early compressive strength were subjected to a correlation analysis on the basis of which the relationship between the analyzed features was determined.

Key words: filtration, cement slurry, compressive strength, correlation, Ultrasonic Cement Analyzer.

\section{Wprowadzenie}

Podstawowym celem zabiegu cementowania jest prawidłowe i skuteczne uszczelnienie kolumny rur okładzinowych. Zależnie od rodzaju kolumny rur cele są zróżnicowane, mimo że często się pokrywają. W przypadku np. cementowania kolumny wstępnej podstawowym celem zabiegu uszczelniania jest zapobieganie erozji, która może nastąpić w przestrzeni pozarurowej (Habrat et al., 1980; Nelson 1990; Bensted, 2004; http://fizyka.maszyna.pl/wstep_widmo.php, 2017). Natomiast $\mathrm{w}$ trakcie uszczelniania kolumny rur prowadnikowych wymagane jest skuteczne unieruchomienie tej kolumny oraz odizolowanie wód gruntowych, a także wytworzenie dodatkowego podparcia dla kolumn rur głębiej zapuszczanych. $\mathrm{Z}$ kolei uszczelnienie kolumny technicznej prowadzone jest w celu odizolowania stref o anomalnym gradiencie ciśnienie i stref ucieczki płuczki (Habrat et al., 1980; Nelson, 1990; Rzepka et al., 2012; Kremieniewski, 2019). Najczęściej w tym przypadku stosuje się zaczyny o obniżonej gęstości. Powstały z takich zaczynów płaszcz cementowy charakteryzuje się jednak niskimi wartościami wytrzymałości na ściskanie, co należy uwzględniać z uwagi na możliwość wystąpienia problemów z odczytaniem stanu zacementowania (Rzepka i Stryczek, 2008; Kremieniewski, 2018a,). Z kolei uszczelnienie kolumny rur eksploatacyjnych jest prowadzone w celu wyeliminowania migracji gazu w przestrzeni pierścieniowej dając dobrą izolację strefową (Gawlik i Szymczak, 2006; Kremieniewski i Rzepka, 2016a; Kremieniewski, 2016, 2018).

Obecny w przestrzeni pierścieniowej lub pozarurowej płaszcz cementowy powstaje ze świeżego zaczynu na skutek wymieszania suchego cementu określoną ilością wody, które to składniki ulegają reakcjom hydratacji (Radecki i Witek, 1999; Bensted i Smith, 2008; Kremieniewski i Rzepka, 2018). Jednak, aby uzyskać odpowiednią konsystencję umożliwiającą przetłoczenie zaczynu przez niewielkie średnice otworu niezbędne jest niekiedy zwiększenie ilości wody (Radecki i Witek, 1999; Kremieniewski i Rzepka, 2018). Zaczyn cementowy podczas tłoczenia $\mathrm{w}$ przestrzeń pierścieniową znajduje się w warunkach dynamicznych, ale po zakończeniu tłoczenia, warunki te zmieniają się na statyczne, a zaczyn ulega hydratacji, w trakcie której rozpoczyna się etap budowania wytrzymałości strukturalnej oraz w dalszym czasie wytrzymałości mechanicznej (Dębińska, 2013). Podczas tego procesu następuje zmniejszanie się początkowej ilości wody, która jest odfiltrowywana z zaczynu w strefy chłonne. Warunkiem koniecznym, aby zaczyn związał w czasie dostosowanym według projektu do warunków geologiczno-technicznych oraz aby uzyskał wymagane wartości wytrzymałości na ściskanie, jest obecność odpowiedniej ilości wody i „utrzymanie” jej przez okres hydratacji i budowania wczesnej wytrzymałości mechanicznej. W celu określenia zdolności zaczynu do „utrzymania” określonej porcji wody w strukturze płynnego zaczynu prowadzone są badania filtracji. Zaczyn cementowy wykazujący duże wartości filtracji może gęstnieć znacznie szybciej niż jest to przewidziane w projekcie cementowania (Kudowski, 2010; Stryczek et al., 2016; Kremieniewski, 2018b). Dodatkowo zmniejsza się objętość takiego nadmiernie filtrującego zaczynu i następuje „odklejanie się” płaszcza cementowego od powierzchni styku, czego efektem może być powstawanie tzw. „kieszeni wodnych” (Radecki i Witek, 1999; Kremieniewski i Rzepka, 2018). Nadmierne wartości filtracji mogą się również przyczynić do znacznego zmniejszenia przepuszczalności strefy przyodwiertowej złoża na skutek odfiltrowywania wody w pokłady porowate złóż ropno-gazowych (Kremieniewski i Rzepka, 2016b). Wydzielający się z zaczynu filtrat wpływa na zmianę przepuszczalności kolektora, co jest uzależnione głównie od składu chemicznego i mineralogicznego zaczynu, od jego parametrów reologicznych i właściwości fizykochemicznych tworzącego się filtratu (Stryczek et al., 2009, 2014). Wymywanie cząstek, a następnie rozpuszczanie 
składników złoża przez filtrat prowadzi do powstawania nieodwracalnych zmian współczynnika przepuszczalności formacji skalnej. Nadmierna wartość filtracji skutkuje wzrostem parametrów reologicznych tłoczonego zaczynu. Tworzący się natomiast stwardniały zaczyn cementowy, który posiada na skutek odfiltrowania mniej wody w swojej strukturze, może nie uzyskać odpowiednich i wymaganych wartości wytrzymałości na ściskanie (Wiśniowski et al., 2007; Kremieniewski, 2018c).

Jak wiadomo, skuteczność zaizolowania przestrzeni międzyrurowej lub pozarurowej zależy miedzy innymi od prawidłowo zaprojektowanej receptury zaczynu uszczelniającego. Jakość stanu zacementowania określana jest podczas pomiarów geofizycznych. Ocena stanu zacementowania pozwala określić czy założone w projekcie cele zostały osiągnięte, a przede wszystkim czy cementowanie było skutecznie przeprowadzone. W przemyśle naftowym pojawiają się bowiem problemy dotyczące niskiej oceny stanu zacementowania rur okładzinowych. Szuka się przyczyn tego zjawiska, tym bardziej, że aparatura pomiarowa jest coraz nowocześniejsza oraz używa się wysokiej klasy sond do oceny jakości stanu zacementowania otworów. Teoretycznie nie powinno być problemów związanych z określeniem zacementowania jednak praktyka pokazuje, że pojawiają się zagadnienia warte rozważenia. Podczas badań prowadzonych w ostatnich miesiącach określany jest wpływ parametrów mechanicznych płaszcza cementowego na wyniki interpretacji profilowań geofizycznych, co może się przyczynić do wzrostu miarodajności określenia stanu zacementowania kolumny rur (Kremieniewski et al., 2015; Kremieniewski i Rzepka, 2017). Należy jednak nadmienić, że jednym z wielu czynników decydujących o jakości profilowania sondy, jest czas wiązania zaczynu cementowego, co przekłada się na parametry mechaniczne powstałego płaszcza cementowego. Na rysunku 1 przedawniono wpływ czasu wiązania zaczynu cementowego na wyniki profilowania akustycznego (Nelson, 1990). Według powyższej zależności daje się zauważyć, że wraz ze wzrostem czasu wiązania zaczynu wzrasta siła tłumienia sygnału akustycznego $\mathrm{w} \mathrm{dB} / \mathrm{m}$. Wiąże się to ze wzrostem wytrzymałości mechanicznej płaszcza cementowego w jednostce czasu. Potwierdzeniem powyższego jest przedstawiony na rysunkach 2 oraz 3 schemat przebiegu krzywej amplitudy sygnału rurowego po 3 dniach hydratacji zaczynu oraz po 8 dniach wiązania (Nelson, 1990). Schemat przebiegu sygnału potwierdza, że jednym z bardziej istotnych czynników

wpływających na wyniki stanu zacementowania jest wczesna wytrzymałość na ściskanie powstałego stwardniałego zaczynu cementowego. Ponadto parametry zaczynu decydują o skuteczności uszczelnienia i wieloletniej trwałości płaszcza cementowego. Niekiedy może się zdarzyć, że płaszcz cementowy z niektórych rodzajów zaczynów posiadać będzie bardzo niską wartość impedancji akustycznej i po krótkim czasie hydratacji będą trudności w odróżnieniu zaczynu cementowego od wody, kiedy tworzywo cementowe nie zbuduje odpowiedniej wytrzymałości mechanicznej w początkowym okresie hydratacji (Nelson, 1990).

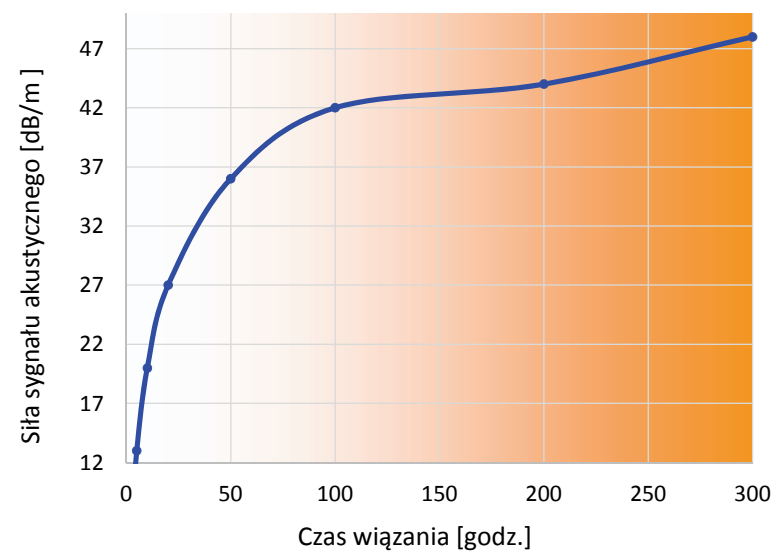

Rys. 1. Wpływ czasu wiązania zaczynu cementowego na wyniki profilowania akustycznego

Fig. 1. Influence of setting time of cement slurry on the results of acoustic $\log$

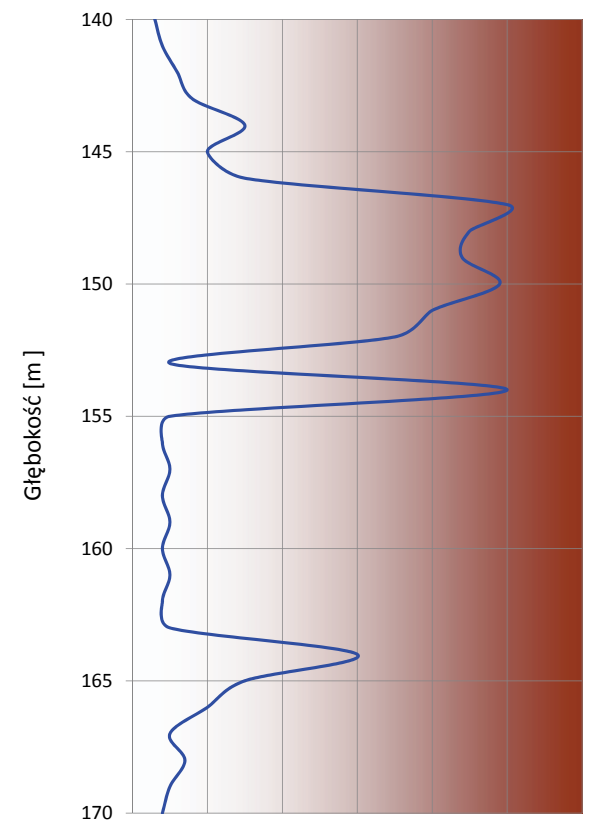

Rys. 2. Schemat przebiegu krzywej amplitudy thumienia sygnału rurowego po

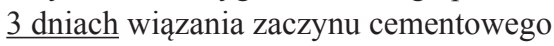

Fig. 2. Diagram of the amplitude curve of the signal attenuation after 3 days of binding of cement slurry

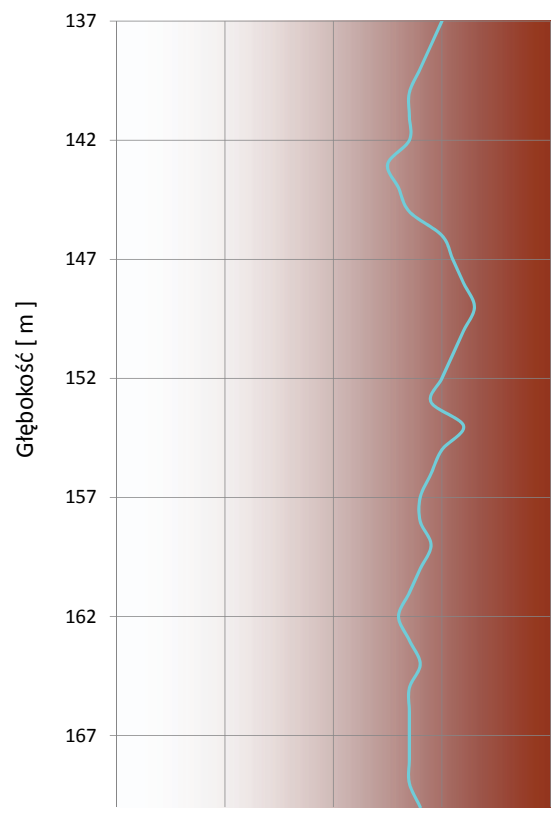

Rys. 3. Schemat przebiegu krzywej amplitudy thumienia sygnału rurowego po

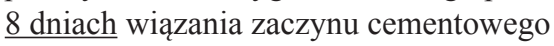

Fig. 3. Diagram of the amplitude curve of the signal attenuation after 8 days of binding of cement slurry 
Wytrzymałość na ściskanie we wczesnym etapie hydratacji możliwa jest do określenia za pomocą ultradźwiękowego analizatora cementu. Urządzenie pozwala na nieniszczący pomiar budowania wytrzymałości mechanicznej wiążącego zaczynu w warunkach otworopodobnych, czyli w temperaturze i ciśnieniu odpowiadającym warunkom występującym w otworze (Dębińska, 2013). Pomiar stanu transformacji zaczynu ze stanu płynnego przez formę żelową, aż do wiążącego i związanego stwardniałego zaczynu badany jest w sposób ciągły, a wyniki są zapisywane w formie graficznej. Obecna w zaczynie woda bezpośrednio wpływa na wiązanie zaczynu i narastanie jego wytrzymałości. Z kolei wczesna wytrzymałość na ściskanie powstałego płaszcza cementowego jest bardzo istotnym parametrem pod kątem uzyskania odpowiedniej stabilizacji, szczelności i trwałości otworu. W związku z powyższym w dalszej części niniejszej publikacji omówione zostały wybrane wyniki badań filtracji, których wartości zostały skorelowane z wynikami pomiarów wczesnej wytrzymałości mechanicznej określonej za pomocą ultradźwiękowego analizatora cementu.

\section{Przebieg prac badawczych}

Prace badawcze na podstawie, których wykonana została korelacja wyników badań filtracji i wczesnej wytrzymałości mechanicznej określonej za pomocą ultradźwiękowego analizatora cementu, zrealizowane zostały w Laboratorium Zaczynów Uszczelniających INiG - PIB w oparciu o normy: PN-85/G-02320 Cementy i zaczyny cementowe do cementowania w otworach wiertniczych; PN-EN 10426-2 Przemyst naftowy i gazowniczy. Cementy i materialy do cementowania otworów. Czesść 2: Badania cementów wiertniczych oraz API SPEC 10 Specification for materials and testing for well cements.

W celu przeprowadzenia analizy korelacyjnej sporządzono 8 receptur zaczynów przeznaczonych do uszczelniania kolumn rur okładzinowych $\mathrm{w}$ warunkach temperatury około $30^{\circ} \mathrm{C}$ i ciśnienia około $5 \mathrm{MPa}$. Wodą zarobową do sporządzania próbek była woda wodociągowa. Zaczyny oznaczone numerami 1 oraz 5 to receptury kontrolne. Wszystkie zaczyny to receptury z dodatkiem lateksu i 20\% mikrocementu mającego za zadanie doszczelnienie matrycy cementowej. Dodatkowo receptury zaczynów zawierały $20 \%$ mikrosfer w celu obniżenia gęstości zaczynu. W celu wyeliminowania frakcjonowania dodatków lekkich zastosowano $0,3 \%\left(\mathrm{BWOW}^{1}\right)$ bentonitu. Zaczyny zawierały środek odpieniający, upłynniający i antyfiltracyjny w celu uzyskania wymaganych wartości parametrów technologicznych. Wymagany czas gęstnienia uzyskano po zastosowaniu 3,5\%-owej ilości akceleratora wiązania. Wszystkie receptury sporządzono na bazie cementu portlandzkiego klasy CEM I 42,5 R, a użyte środki dozowano w stosunku do masy cementu $\left(\right.$ BWOC $\left.^{2}\right)$. Zaczyny pierwszej grupy $\mathrm{nr} 2,3,4$, oraz drugiej grupy numery $6,7,8$ posiadały mączkę krzemionkową w ilościach odpowiednio 10\%,20\% oraz $30 \%$. Receptury zaczynów zestawionych w pierwszej grupie (tab. 1) charakteryzowały się stałą wartością współczynnika wodno-cementowego dla wszystkich składów. W recepturach zaczynów należących do drugiej grupy (tab. 3) współczynnik wodno cementowy był zwiększany wraz ze wzrostem ilości mączki krzemionkowej.

Parametry badanych receptur zaczynów należących do pierwszej grupy zestawione zostały w tabeli 2 . Parametry drugiej grupy zaczynów zestawiono w tabeli 4 .

Analizując uzyskane wyniki badań dla receptur o stałym współczynniku wodno-cementowym i wzrastającej ilości mączki krzemionkowej, stwierdzono, że obecność drobnoziarnistej frakcji $\mathrm{SiO}_{2}$ w recepturze zaczynu powoduje wzrost wczesnej wytrzymałości na ściskanie (po 12, 24 i 48 godzinach) badanych za ${ }^{1} \mathrm{BWOW}-(\mathrm{z}$ ang. by weight of water $)-\mathrm{w}$ stosunku do objętości wody
${ }^{2} \mathrm{BWOC}-(\mathrm{z}$ ang. by weight of cement $)-\mathrm{w}$ stosunku do masy cementu

Tabela 1. Składy wytypowanych zaczynów (pierwsza grupa) dla warunków otworowych o temperaturze około $30^{\circ} \mathrm{C}$ i ciśnieniu około $5 \mathrm{MPa}$ (stały współczynnik wodno-cementowy)

Table 1. Compositions of selected slurries (first group) for borehole conditions with a temperature of approx. $30^{\circ} \mathrm{C}$ and a pressure of approx. $5 \mathrm{MPa}$ (constant water-cement ratio)

\begin{tabular}{|l|c|c|c|c|}
\hline \multicolumn{1}{|c|}{ SKLAD } & $\begin{array}{c}\text { ZACZYN 1 } \\
\text { kontrolny }\end{array}$ & ZACZYN 2 & ZACZYN 3 & ZACZYN 4 \\
\hline \hline Współcz. wodno-cementowy & $\mathrm{w} / \mathrm{c}=0,64$ & $\mathrm{w} / \mathrm{c}=0,64$ & $\mathrm{w} / \mathrm{c}=0,64$ & $\mathrm{w} / \mathrm{c}=0,64$ \\
\hline Bentonit (bwow) & $0,3 \%$ & $0,3 \%$ & $0,3 \%$ & $0,3 \%$ \\
\hline Środek odpieniający & $1,0 \%$ & $1,0 \%$ & $1,0 \%$ & $1,0 \%$ \\
\hline Środek upłynniający & $0,3 \%$ & $0,3 \%$ & $0,3 \%$ & $0,3 \%$ \\
\hline Środek antyfiltracyjny & $0,3 \%$ & $0,3 \%$ & $0,3 \%$ & $0,3 \%$ \\
\hline Lateks & $10,0 \%$ & $10,0 \%$ & $10,0 \%$ & $10,0 \%$ \\
\hline Stabilizator lateksu & $2,0 \%$ & $2,0 \%$ & $2,0 \%$ & $2,0 \%$ \\
\hline Środek skracający czas gęstnienia & $3,5 \%$ & $3,5 \%$ & $3,5 \%$ & $3,5 \%$ \\
\hline Mączka krzemionkowa SBC & - & $10,0 \%$ & $20,0 \%$ & $30,0 \%$ \\
\hline Mikrocement & $20,0 \%$ & $20,0 \%$ & $20,0 \%$ & $20,0 \%$ \\
\hline Mikrosfera & $20,0 \%$ & $20,0 \%$ & $20,0 \%$ & $20,0 \%$ \\
\hline Cement CEM I 42,5R & $100,0 \%$ & $100,0 \%$ & $100,0 \%$ & $100,0 \%$ \\
\hline
\end{tabular}


Tabela 2. Parametry badanych receptur zaczynów (pierwsza grupa) dla warunków otworowych o temperaturze około $30^{\circ} \mathrm{C}$ i ciśnieniu około $5 \mathrm{MPa}$ (stały współczynnik wodno-cementowy)

Table 2. Parameters of the tested slurries (first group) for borehole conditions with a temperature of about $30^{\circ} \mathrm{C}$ and a pressure of about $5 \mathrm{MPa}$ (constant water-cement ratio)

\begin{tabular}{|c|c|c|c|c|c|}
\hline \multicolumn{2}{|l|}{ Parametr } & $\begin{array}{c}\text { ZACZYN } 1 \\
\text { kontrolny }\end{array}$ & ZACZYN 2 & ZACZYN 3 & ZACZYN 4 \\
\hline \multicolumn{2}{|l|}{ Gęstość $\left[\mathrm{kg} / \mathrm{m}^{3}\right]$} & 1470 & 1500 & 1530 & 1560 \\
\hline \multirow{3}{*}{$\begin{array}{l}\text { Wartość wczesnej wytrzymałości } \\
\text { na ściskanie }[\mathrm{MPa}]\end{array}$} & po 12 godzinach hydratacji & 4,0 & 6,0 & 7,0 & 8,0 \\
\hline & po 24 godzinach hydratacji & 8,0 & 10,0 & 11,0 & 12,0 \\
\hline & po 48 godzinach hydratacji & 11,0 & 14,0 & 15,0 & 16,0 \\
\hline \multicolumn{2}{|c|}{ Czas startu narastania wytrzymałości mechanicznej w UCA $\mathrm{UC}^{3}$ [godz:min] } & $6: 20$ & $4: 20$ & $2: 40$ & $2: 20$ \\
\hline \multirow{2}{*}{$\begin{array}{l}\text { Czas po jakim zaczyn uzyskał określoną } \\
\text { wytrzymałość na ściskanie [godz:min] }\end{array}$} & $3 \mathrm{MPa}$ & $10: 22$ & $7: 15$ & $5: 21$ & $5: 14$ \\
\hline & $4 \mathrm{MPa}$ & $12: 11$ & $8: 37$ & $6: 28$ & $6: 16$ \\
\hline \multicolumn{2}{|l|}{ Filtracja $\left[\mathrm{cm}^{3} / 30 \mathrm{~min}\right]$} & 66,0 & 64,0 & 59,0 & 54,0 \\
\hline
\end{tabular}

Tabela 3. Składy wytypowanych zaczynów (druga grupa) dla warunków otworowych o temperaturze około $30^{\circ} \mathrm{C}$ i ciśnieniu około $5 \mathrm{MPa}$ (wzrastający współczynnik wodno-cementowy)

Table 3. Compositions of selected slurries (second group) for borehole conditions with a temperature of approx. $30^{\circ} \mathrm{C}$ and a pressure of about $5 \mathrm{MPa}$ (increasing water-cement ratio)

\begin{tabular}{|l|c|c|c|c|}
\hline \multicolumn{1}{|c|}{ SKLAD } & $\begin{array}{c}\text { ZACZYN 5 } \\
\text { kontrolny }\end{array}$ & ZACZYN 6 & ZACZYN 7 & ZACZYN 8 \\
\hline \hline Współczynnik wodno-cementowy & $\mathrm{w} / \mathrm{c}=0,64$ & $\mathrm{w} / \mathrm{c}=0,69$ & $\mathrm{w} / \mathrm{c}=0,74$ & $\mathrm{w} / \mathrm{c}=0,79$ \\
\hline Bentonit (bwow) & $0,3 \%$ & $0,3 \%$ & $0,3 \%$ & $0,3 \%$ \\
\hline Środek odpieniający & $1,0 \%$ & $1,0 \%$ & $1,0 \%$ & $1,0 \%$ \\
\hline Środek upłynniający & $0,3 \%$ & $0,3 \%$ & $0,3 \%$ & $0,3 \%$ \\
\hline Środek antyfiltracyjny & $0,3 \%$ & $0,3 \%$ & $0,3 \%$ & $0,3 \%$ \\
\hline Lateks & $10,0 \%$ & $10,0 \%$ & $10,0 \%$ & $10,0 \%$ \\
\hline Stabilizator lateksu & $2,0 \%$ & $2,0 \%$ & $2,0 \%$ & $2,0 \%$ \\
\hline Środek skracający czas gęstnienia & $3,5 \%$ & $3,5 \%$ & $3,5 \%$ & $3,5 \%$ \\
\hline Mączka krzemionkowa SBC & - & $10,0 \%$ & $20,0 \%$ & $30,0 \%$ \\
\hline Mikrocement & $20,0 \%$ & $20,0 \%$ & $20,0 \%$ & $20,0 \%$ \\
\hline Mikrosfera & $20,0 \%$ & $20,0 \%$ & $20,0 \%$ & $20,0 \%$ \\
\hline Cement CEM I 42,5R & $100,0 \%$ & $100,0 \%$ & $100,0 \%$ & $100,0 \%$ \\
\hline
\end{tabular}

Tabela 4. Parametry badanych receptur zaczynów (druga grupa) dla warunków otworowych o temperaturze około $30^{\circ} \mathrm{C}$ i ciśnieniu około $5 \mathrm{MPa}$ (wzrastajacy współczynnik wodno-cementowy)

Table 4. Parameters of the tested slurries formulas (second group) for borehole conditions with a temperature of about $30^{\circ} \mathrm{C}$ and a pressure of about $5 \mathrm{MPa}$ (increasing water-cement ratio)

\begin{tabular}{|c|c|c|c|c|c|}
\hline \multicolumn{2}{|l|}{ Parametr } & $\begin{array}{c}\text { ZACZYN } 5 \\
\text { bazowy }\end{array}$ & ZACZYN 6 & ZACZYN 7 & ZACZYN 8 \\
\hline \multicolumn{2}{|l|}{ Gęstość $\left[\mathrm{kg} / \mathrm{m}^{3}\right]$} & 1470 & 1490 & 1510 & 1530 \\
\hline \multirow{3}{*}{$\begin{array}{l}\text { Wartość wczesnej wytrzymałości } \\
\text { na ściskanie }[\mathrm{MPa}]\end{array}$} & po 12 godzinach hydratacji & 4,0 & 4,0 & 4,0 & 6,0 \\
\hline & po 24 godzinach hydratacji & 8,0 & 9,0 & 9,0 & 11,0 \\
\hline & po 48 godzinach hydratacji & 11,0 & 12,0 & 13,0 & 15,0 \\
\hline \multicolumn{2}{|c|}{ Czas startu narastania wytrzymałości mechanicznej w UCA [godz:min] } & $6: 20$ & $6: 10$ & 6:00 & $4: 40$ \\
\hline \multirow{2}{*}{$\begin{array}{l}\text { Czas po jakim zaczyn uzyskał określoną } \\
\text { wytrzymałość na ściskanie [godz:min] }\end{array}$} & $3 \mathrm{MPa}$ & $10: 22$ & $9: 57$ & $10: 04$ & $7: 27$ \\
\hline & $4 \mathrm{MPa}$ & $12: 11$ & $11: 31$ & $11: 32$ & $8: 35$ \\
\hline \multicolumn{2}{|l|}{ Filtracja $\left[\mathrm{cm}^{3} / 30 \mathrm{~min}\right]$} & 66,0 & 74,0 & 80,0 & 83,0 \\
\hline
\end{tabular}

${ }^{3}$ UCA - Ultrasonic Cement Analyzer - Ultradźwiękowy analizator cementu 
pomocą Ultrasonic Cement Analyzer (rys. 4). Zaobserwowano także, iż czas startu narastania wytrzymałości mechanicznej (rys. 5) ulega przyspieszeniu wraz ze wzrostem koncentracji mączki krzemionkowej. W zaczynie kontrolnym nr 1 początek budowania wytrzymałości mechanicznej w UCA zaobserwowano po upływie 6 godzin i 20 minut (rys. 5). Natomiast największa z zastosowanych koncentracji $\mathrm{SiO}_{2}$, wynosząca $30 \%$ (BWOC) powodowała skrócenie tego czasu do wartości wynoszącej 2 godziny i 20 minut (rys. 6). Również czas, po jakim stwardniały zaczyn osiągnął wartość $3 \mathrm{MPa}$ oraz $4 \mathrm{MPa}$ uległ skróceniu wraz ze wzrostem ilości mączki krzemionkowej. Czas osiągania wartości $3 \mathrm{MPa}$ w zaczynie kontrolnym wynosił ponad 10 godzin. Już 10\%-owa ilość mączki krzemionkowej skutkowała-skróceniem tego czasu o ponad 3 godziny, co przedstawiono na rysunku 6 . Dalsze wzrastające ilości $\mathrm{SiO}_{2}$ powodowały niemal liniowe skracanie czasu osiągania wytrzymałości 3 MPa. Określenie wartości $3 \mathrm{MPa}$ oraz $4 \mathrm{MPa}$ jest istotne z punktu widzenia możliwości przystąpienia do dalszych prac na otworze po wykonaniu zabiegu cementowania, dlatego też wartości te zostały poddane badaniom. Obecność mączki krzemionkowej w recepturze zaczynu skutkuje korzystnym obniżeniem wartości filtracji zaczynu wraz ze wzrostem koncentracji $\mathrm{SiO}_{2}$. Zależność tę przedstawiono na rysunku 7, gdzie zaczyn kontrolny posiadał wartość filtracji równą $66 \mathrm{~cm}^{3} / 30 \mathrm{mi}-$ nut. Wprowadzenie 30\%-owej ilości mączki krzemionkowej spowodowało redukcję wartości filtracji o $12 \mathrm{~cm}^{3}$.

W drugiej grupie zaczynów przedstawionej w tabeli 3, których to receptur parametry zostały zestawione $\mathrm{w}$ tabeli 4 , wprowadzono wzrastający współczynnik wodno-cementowy. Ilość wody w recepturach zwiększana była (zgodnie $\mathrm{z}$ ilością podaną $\mathrm{w}$ ta-

beli 3) wraz ze wzrostem ilości wprowadzonej do receptury mączki krzemionkowej. Na podstawie analizy uzyskanych wyników badań stwierdzono, że po 12 godzinach wiązania receptury zawierające $10 \%$ i 20\% mączki krzemionkowej posiadały wytrzymałość taką samą jak próbka kontrolna (4 MPa). Jest to korzystne, ponieważ wzrastająca ilość wody w zaczynie, dozowana w celu poprawy parametrów reologicznych, powoduje zazwyczaj obniżenie wartości wczesnej wytrzymałości mechanicznej, natomiast w tym przypadku uzyskano stałą wartość. Wytrzymałość na ściskanie po 24 i 48 godzinach, mimo wzrastającej ilości wody, uległa niewielkiemu wzrostowi w porównaniu do próbki kontrolnej, co obrazuje rysunek 8 . Analizując uzyskane wyniki początku narastania wczesnej wytrzymałości Cement Analyzer

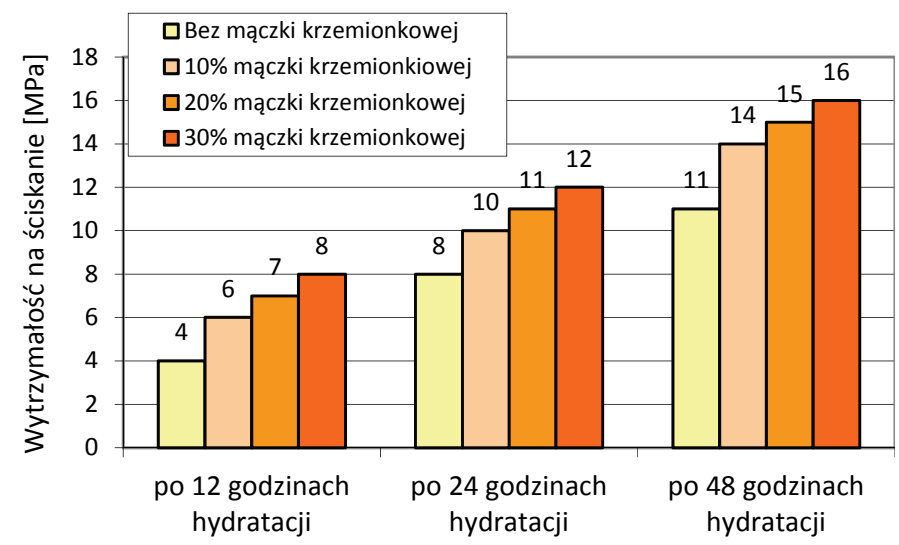

Rys. 4. Zestawienie wczesnej wytrzymałości na ściskanie receptur o stałym współczynniku wodno-cementowym

Fig. 4. A comparison of the early compressive strength of recipes with a constant water-cement ratio

Rys. 5. Wykres narastania wczesnej wytrzymałości mechanicznej. Badanie za pomocą Ultrasonic Cement Alanyzer

Fig. 5. Graph of growing early mechanical strength. Testing using the Ultrasonic

mechanicznej, stwierdzono nieznaczne skracanie się tego czasu wraz ze wzrostem ilości $\mathrm{SiO}_{2}$. Czas osiągania referencyjnych wartości wytrzymałości na ściskanie równych $3 \mathrm{MPa}$ oraz $4 \mathrm{MPa}$ uległ skróceniu (w porównaniu do próbki kontrolnej) po zastosowaniu 10\%-owej koncentracji mączki krzemionkowej. Wzrost koncentracji $\mathrm{SiO}_{2}$ do wartości $20 \%$ nie powodował znacznej różnicy. Natomiast wartość 30\% dwutlenku krzemu w zaczynie skutkowała dalszym skróceniem czasu osiągania wytrzymałości na ściskanie zarówno wartości $3 \mathrm{MPa}$ jak i wartości $4 \mathrm{MPa}$, co przedstawiono na rysunku 9. Wzrastająca ilość wody w recepturze zaczynu, mimo jednoczesnego wzrostu koncentracji mączki krzemionkowej, skutkowała wzrostem wartości filtracji, w zakresie przedstawionym na rysunku 10 . 


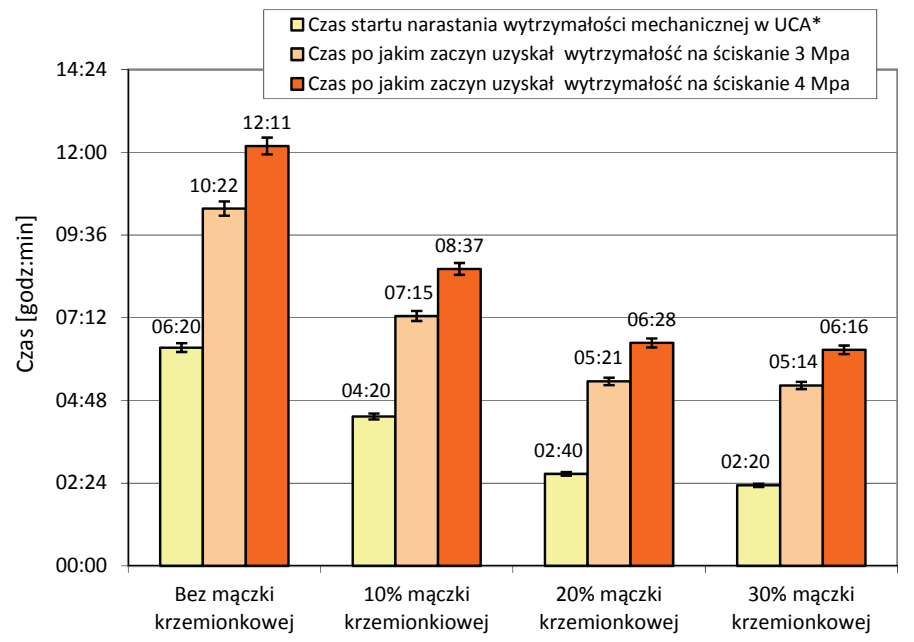

Rys. 6. Zestawienie czasu osiągnięcia wymaganych wartości parametrów mechanicznych

Fig. 6. List of the time required to achieve the required mechanical parameters

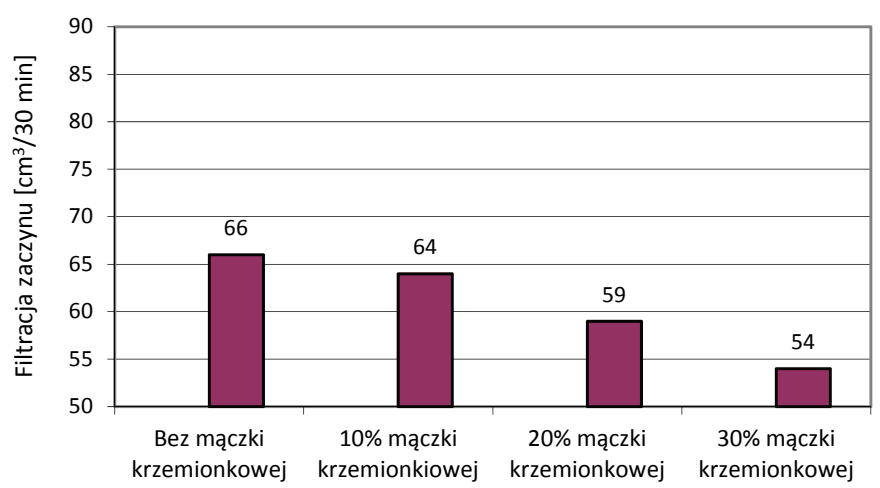

Rys. 7. Zestawienie wartości filtracji zaczynów o stałym współczynniku wodno-cementowym

Fig. 7. List of the slurries filtration values with a constant watercement ratio

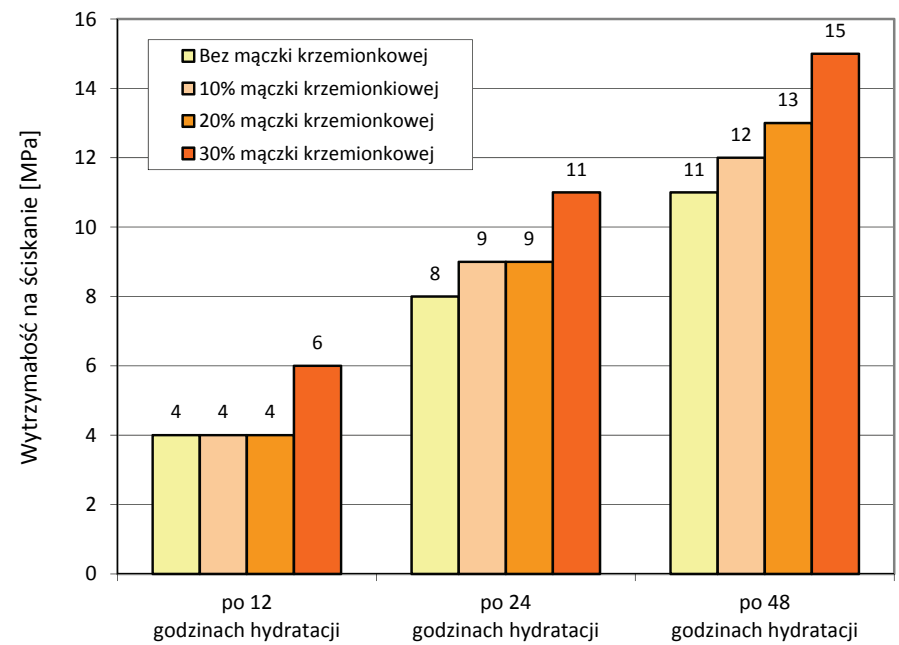

Rys. 8. Zestawienie wczesnej wytrzymałości na ściskanie receptur o wzrastającym współczynniku wodno-cementowym

Fig. 8. List of the value of early compressive strength of recipes with increasing water-cement ratio

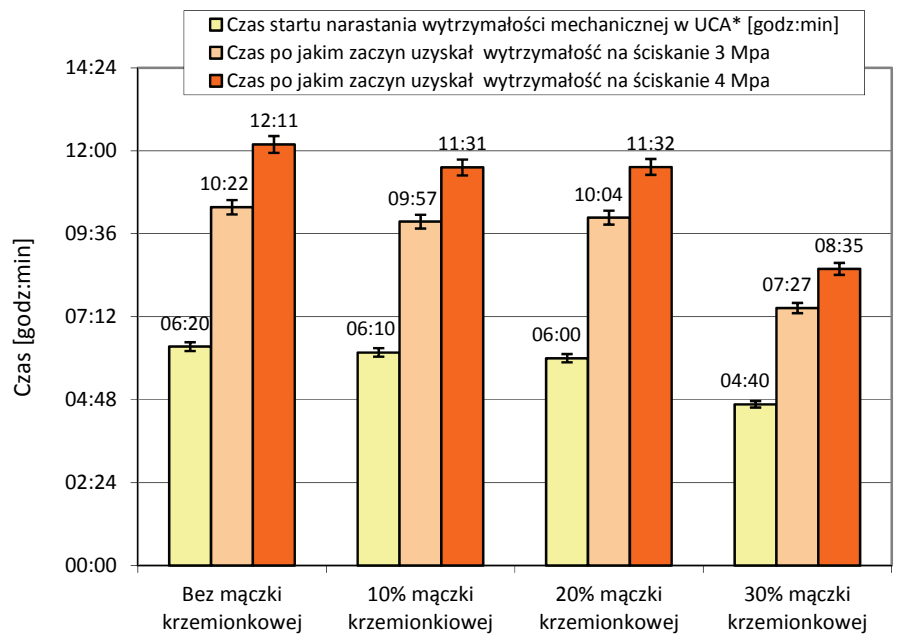

Rys. 9. Zestawienie czasu osiągnięcia wymaganych wartości parametrów mechanicznych (wzrastające wodno-cementowy)

Fig. 9. List of time required to achieve the required mechanical parameters (increasing water-cement ratio)

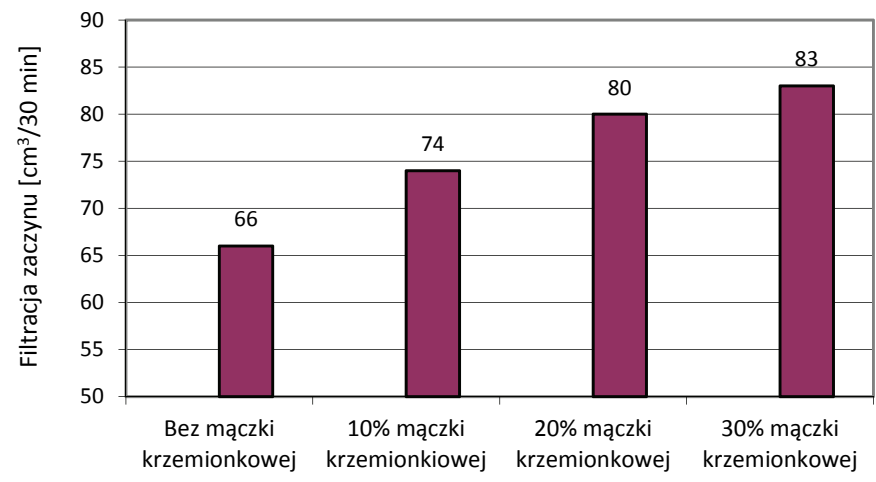

Rys. 10. Zestawienie wartości filtracji zaczynów o wzrastającym współczynniku wodno-cementowym

Fig. 10. Comparison of slurry filtration values with increasing water-cement ratio

\section{Korelacja wyników badań}

Analizie porównawczej poddano kolejne uzyskane wartości filtracji zaczynów o wzrastającej koncentracji mączki krzemionkowej, czyli od receptury kontrolnej (niezawierającej mączki krzemionkowej) do receptury zawierającej $30 \%$ (BWOC) $\mathrm{SiO}_{2}$ oraz wartości wczesnej wytrzymałości, tj.:

- wytrzymałość na ściskanie po 12 godzinach hydratacji;

- wytrzymałość na ściskanie po 24 godzinach hydratacji;

- wytrzymałość na ściskanie po 48 godzinach hydratacji.

Ponadto korelacji poddano wartości filtracji oraz:

- czas startu narastania wytrzymałości mechanicznej w UCA;

- czas, po jakim zaczyn uzyskał wytrzymałość na ściskanie $3 \mathrm{MPa}$;

- czas, po jakim zaczyn uzyskał wytrzymałość na ściskanie $4 \mathrm{MPa}$.

Wyboru takiego dokonano ze względu na wpływ filtracji zaczynu na parametry mechaniczne, które są szczególnie 
ważne podczas projektowania receptur zaczynów o obniżonej gęstości. Podczas analizy powyższych wyników dokonano podstawowej korelacji przy użyciu współczynnika Pearsona, który wykorzystuje się podczas badania związków prostoliniowych zmienności, gdzie zmiana jednych wartości skutkuje proporcjonalną zmianą średnich wartości drugiej cechy. Współczynnik korelacji Pearsona obliczono według wzoru (1).

$$
r_{x, y}=\frac{\operatorname{cov}(x, y)}{S d_{x} \cdot S d_{y}}
$$

gdzie:

$x$ - uzyskane wartości filtracji kolejnych zaczynów;

$y$ - analizowane wartości wybranego parametru mechanicznego kolejnych zaczynów.

\section{Interpretacja siły związków korelacyjnych}

Współczynnika korelacji Pearsona:

- poniżej 0,2 - korelacja słaba (praktycznie brak związku);

- 0,2-0,4-korelacja niska (zależność wyraźna);

- 0,4-0,6 - korelacja umiarkowana (zależność istotna);

- $0,6-0,8$ - korelacja wysoka (zależność znaczna);

- $\quad 0,8-0,9$ - korelacja bardzo wysoka (zależność bardzo duża);

- $0,9-1,0$ - korelacja całkowita (zależność praktycznie pełna).
Na początku obliczono kowariancję (2), która informuje o liniowej zależności między zmiennymi losowymi $x$ i $y$. Obliczono także estymator największej wiarygodności $S d_{x}, S d_{y}$ (3), (4), dający najmniejsze wartości odchyleń:

$$
\begin{aligned}
\operatorname{cov}(x, y) & =\frac{\sum\left(x_{i}-\bar{x}\right)\left(y_{i}-\bar{y}\right)}{n} \\
S d_{x} & =\sqrt{\frac{\sum\left(x_{i}-\bar{x}\right)^{2}}{n}} \\
S d_{y} & =\sqrt{\frac{\sum\left(y_{i}-\bar{y}\right)^{2}}{n}}
\end{aligned}
$$

gdzie:

$\bar{x}$ - uzyskane wartości filtracji kolejnych zaczynów (wartość średnia);

$\bar{y}$ - analizowane wartości wybranego parametru mechanicznego kolejnych zaczynów (wartość średnia),

$n$ - liczba prób.

Ostatnim krokiem było obliczenie wskaźnika determinacji liniowej (5) informującego o procencie liniowej zależności pomiędzy zmiennymi: zależną i niezależną.

$$
W D=r_{x y}{ }^{2} \cdot 100 \%
$$

Uzyskane wyniki kwadratu współczynnika korelacji, wskaźnika determinacji liniowej oraz równania liniowej regresji

Tabela 5. Wartości równania liniowej regresji $(y=\mathrm{ax}=\mathrm{b})$, kwadratu współczynnika korelacji $\left(R^{2}\right)$ oraz wskaźnika determinacji liniowej analizowanych cech $(W D)$ dla zaczynów o stałym współczynniku wodno-cementowym (pierwsza grupa)

Table 5. The values of the linear regression equation $(y=\mathrm{ax}=\mathrm{b})$, the correlation coefficient $\left(R^{2}\right)$ and the linear determination index of the analyzed features $(W D)$ for slurries with a constant water-cement ratio (first group)

\begin{tabular}{|l|c|c|c|}
\hline \multicolumn{1}{|c|}{ Rodzaj korelowanych parametrów } & Równanie regresji & Wartość $\boldsymbol{R}^{2}$ & Wartość $\boldsymbol{W D}$ \\
\hline \hline Filtracja - wytrzymałość na ściskanie po 12 godzinach hydratacji & $y=-2,9429 \mathrm{x}+79,143$ & $R^{2}=0,8735$ & $W D=87,4 \%$ \\
\hline Filtracja - wytrzymałość na ściskanie po 24 godzinach hydratacji & $y=-2,9429 \mathrm{x}+90,914$ & $R^{2}=0,8735$ & $W D=87,4 \%$ \\
\hline Filtracja - wytrzymałość na ściskanie po 48 godzinach hydratacji & $y=-2,2143 \mathrm{x}+91,75$ & $R^{2}=0,7913$ & $W D=79,1 \%$ \\
\hline Filtracja - czas startu narastania wytrzymałości mechanicznej w UCA & $y=64,066 \mathrm{x}+50,295$ & $R^{2}=0,8283$ & $W D=82,8 \%$ \\
\hline Filtracja - czas, po jakim zaczyn uzyskał wytrzymałość na ściskanie 3 MPa & $y=46,383 x+47,125$ & $R^{2}=0,7419$ & $W D=74,2 \%$ \\
\hline Filtracja - czas, po jakim zaczyn uzyskał wytrzymałość na ściskanie 4 MPa & $y=40,639 x+46,555$ & $R^{2}=0,7486$ & $W D=74,9 \%$ \\
\hline
\end{tabular}

Tabela 6. Wartości równania liniowej regresji $(y=\mathrm{ax}=\mathrm{b})$, kwadratu współczynnika korelacji $\left(R^{2}\right)$ oraz wskaźnika determinacji liniowej analizowanych cech $(W D)$ dla zaczynów o zmiennym współczynniku wodno-cementowym (druga grupa)

Table 6. The values of the linear regression equation $(y=\mathrm{ax}=\mathrm{b})$, the correlation coefficient $\left(R^{2}\right)$ and the linear determination index of the analyzed features $(W D)$ for slurries with variable water-cement ratio (second group)

\begin{tabular}{|l|c|c|c|}
\hline \multicolumn{1}{|c|}{ Rodzaj korelowanych parametrów } & Równanie regresji & Wartość $\boldsymbol{R}^{\mathbf{2}}$ & Wartość $\boldsymbol{W D}$ \\
\hline \hline Filtracja - wytrzymałość na ściskanie po 12 godzinach hydratacji & $y=4,8333 x+54$ & $R^{2}=0,4153$ & $W D=41,5 \%$ \\
\hline Filtracja - wytrzymałość na ściskanie po 24 godzinach hydratacji & $y=5,1053 x+28,526$ & $R^{2}=0,7336$ & $W D=73,4 \%$ \\
\hline Filtracja - wytrzymałość na ściskanie po 48 godzinach hydratacji & $y=4,0857 x+23,657$ & $R^{2}=0,8656$ & $W D=86,6 \%$ \\
\hline Filtracja - czas startu narastania wytrzymałości mechanicznej w UCA & $y=-181,86 x+119,64$ & $R^{2}=0,5931$ & $W D=59,3 \%$ \\
\hline Filtracja - czas, po jakim zaczyn uzyskał wytrzymałość na ściskanie 3 MPa & $y=-95,169 x+113,26$ & $R^{2}=0,5097$ & $W D=51,0 \%$ \\
\hline Filtracja - czas, po jakim zaczyn uzyskał wytrzymałość na ściskanie 4 MPa & $y=-85,398 x+114,73$ & $R^{2}=0,584$ & $W D=58,4 \%$ \\
\hline
\end{tabular}


analizowanych cech zestawiono w tabeli 5 (dla zaczynów o stałym w/c) oraz w tabeli 6 (dla zaczynów o wzrastającym współczynniku wodno-cementowym.

Na podstawie przeprowadzonej analizy korelacyjnej i uzyskanych wartości kwadratu współczynnika korelacji dla analizowanych zaczynów o stałym współczynniku wodno-cementowym stwierdzono wysoką dodatnią korelację pomiędzy analizowanymi cechami, co przestawiono na rysunku 11.

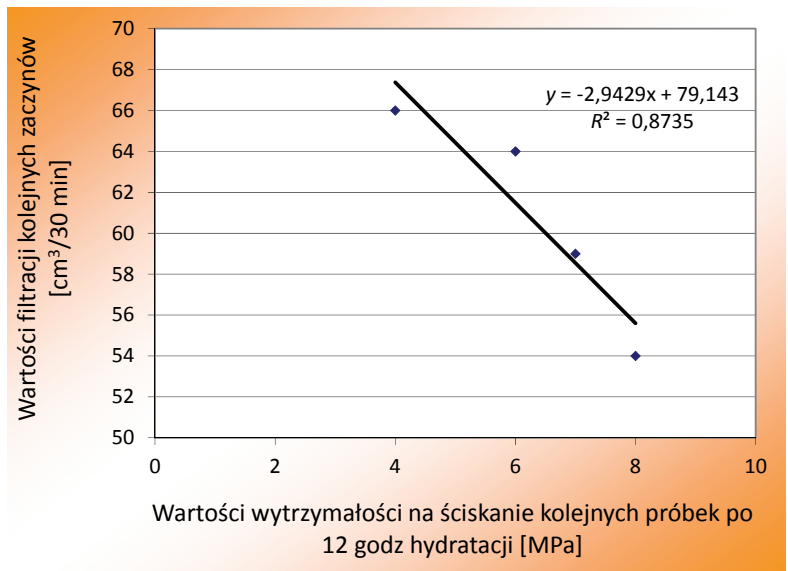

Rys. 11. Zależność wartości filtracji kolejnych zaczynów oraz wartości wytrzymałość na ściskanie próbek po 12 godzinach hydratacji

Fig. 11. The dependence of filtration values of subsequent slurries and values of compressive strength of samples after 12 hours of hydration

Proporcjonalnie do zmniejszającej się wartości filtracji zaczynów wzrasta ich wczesna wytrzymałość na ściskanie. Uzyskane wartości współczynnika $R^{2}$ w zakresie od 0,83 do 0,87 (tab. 5) potwierdzają bardzo dużą zależność poprawy wczesnej wytrzymałości na ściskanie od wartości filtracji zaczynu, która ulega obniżeniu. Również bardzo wysoką korelację uzyskano podczas analizy wpływu filtracji zaczynu na czas rozpoczęcia wzrastania wytrzymałości mechanicznej określanej za pomocą UCA. Obniżające się wartości filtracji w zaczynach o stałym współczynniku wodno-cementowym skutkowały skracaniem czasu, po którym rozpoczynało się narastanie wczesnej wytrzymałości, co potwierdza współczynnik $R^{2}=0,8283$ w tabeli 5. Analizując wyniki kwadratu współczynnika korelacji analizowanych cech w recepturach zaczynów o wzrastającym współczynniku wodno-cementowym (tab. 6), w większości przypadków nie stwierdzono tak mocnych zależności jak w recepturach o stałym w/c. Może to wynikać z faktu, iż wartości filtracji analizowanych zaczynów wzrastały wraz ze wzrostem współczynnika wodno-cementowego. Parametry mechaniczne pozostawały natomiast na stałym poziomie lub ulegały tylko nieznacznej poprawie. Wysoki wskaźnik determinacji liniowej wynoszący $86,5 \%\left(R^{2}=0,8656\right)$ uzyskano jedynie dla korelacji wartości filtracji i wytrzymałości na ściskanie po 48 godzinach hydratacji w tej grupie zaczynów. Może to świadczyć, że po dłuższym czasie (48 godz.) wydzielony z zaczynu filtratu, nie wykazuje już wpływu na przyrost wytrzymałości mechanicznej.

\section{Podsumowanie}

Przeprowadzona analiza korelacyjna może się przyczynić do rozpoznania wpływu wartości filtracji zaczynu na uzyskiwane wartości wczesnej wytrzymałości mechanicznej. Znajomość tej zależności pozwala w bardziej precyzyjny sposób zaprojektować recepturę zaczynu, z którego płaszcz cementowy będzie się charakteryzował wyższymi wartościami parametrów mechanicznych. Na podstawie przeprowadzonej analizy porównywanych parametrów stwierdzono, że:

- redukcja wartości filtracji powoduje poprawę wczesnej wytrzymałości na ściskanie po 12, 24 oraz 48 godzinach hydratacji próbki;

- czas startu narastania wytrzymałości mechanicznej w UCA ulega skróceniu proporcjonalnie do zmniejszającej się wartości filtracji zaczynu;

- czas, po jakim zaczyn uzyska początkowe wartości wczesnej wytrzymałości na ściskanie ( $3 \mathrm{MPa}, 4 \mathrm{MPa}$ ) jest proporcjonalny do wartości filtracji zaczynu;

Ponadto na podstawie przeprowadzonych badań laboratoryjnych stwierdzono, że wzrastająca ilość mączki krzemionkowej w recepturach zaczynów o stałym współczynniku wodno-cementowym powoduje:

- zmniejszenie wartości filtracji świeżego zaczynu w porównaniu do receptury kontrolnej (bez dodatku mączki krzemionkowej);

- wzrost wartości wczesnej wytrzymałości mechanicznej stwardniałego zaczynu cementowego w porównaniu do receptury kontrolnej (bez dodatku mączki krzemionkowej);

- skrócenie czasu rozpoczęcia narastania wytrzymałości na ściskanie.

Z kolei zastosowanie mączki krzemionkowej w recepturach zaczynów, w których proporcjonalnie do ilości $\mathrm{SiO}_{2}$ zwiększono współczynnik wodno-cementowy skutkuje utrzymywaniem na stałym poziomie wartości wczesnych wytrzymałości na ściskanie. Jest to korzystne ze względu na to, iż niezbędna niekiedy dodatkowa ilość wody zarobowej powoduje obniżenie wartości parametrów mechanicznych, natomiast obecność $\mathrm{SiO}_{2}$ pozwala na zniwelowanie tego niekorzystnego efektu.

Należy mieć jednak na uwadze, że receptury zaczynów cementowych mogą wykazywać zróżnicowane zachowanie w zależności od wielu czynników techniczno-technologicznych oraz składu zarówno receptury zaczynu jak również rodzaju zastosowanego cementu. 
Artykuł powstał na podstawie pracy badawczej pt.: Analiza możliwości doszczelnienia mikrostruktury płaszcza cementowego za pomoca nowych domieszek drobnoziarnistych - praca INiG - PIB na zlecenie MNiSW; nr zlecenia: 0044/KW/19, nr archiwalny: DK-4100/34/19.

\section{Literatura}

Bensted J., 2004. Cementy wiertnicze. Cz. 2. Stosowanie cementów wiertniczych do cementowania odwiertów. Cement Wapno Beton, 2: 61-72.

Bensted J., Smith J.R., 2008. Cementy wiertnicze z historycznej perspektywy. Cement Wapno Beton, 3: 124-135.

Dębińska E., 2013. Wyznaczanie statycznej wytrzymałości strukturalnej i wczesnej wytrzymałości mechanicznej zaczynów cementowych. Nafta-Gaz, 2: 134-142.

Gawlik P., Szymczak M., 2006. Migracje gazowe w przestrzeniach międzyrurowych otworów realizowanych na przedgórzu Karpat. Nafta-Gaz,7-8: 349-358.

Habrat S., Raczkowski J., Zawada S. 1980: Technika i technologia cementowań w wiertnictwie. Wydawnictwa Geologiczne, Warszawa.

http://fizyka.maszyna.pl/wstep_widmo.php (dostęp: 1.10.2017).

Kremieniewski M., 2011. Proces migracji gazu w trakcie wiązania zaczynu cementowego. Nafta-Gaz, 3: 175-181.

Kremieniewski M., 2016. Ograniczenie ekshalacji gazu w otworach wiertniczych poprzez modyfikację receptur oraz kształtowanie się struktury stwardniałych zaczynów uszczelniających. Prace Naukowe Instytutu Nafty i Gazu - PIB, 199: 1-400, DOI: 10.18668/PN.199.

Kremieniewski M., 2018a. Poprawa wczesnej wytrzymałości mechanicznej płaszcza cementowego powstałego z zaczynu lekkiego. Nafta-Gaz, 8: 606-612, DOI: 10.18668/NG.2018.08.06.

Kremieniewski M., 2018b. Wpływ środków regulujących czas wiązania na parametry reologiczne zaczynu cementowego. Nafta-Gaz, 11: 828-838, DOI: 10.18668/NG.2018.11.07.

Kremieniewski M., 2018c. Zmiana parametrów technologicznych zaczynu cementowego pod wpływem przeciwsedymentacyjnego dodatku żywicy ksantanowej. Nafta-Gaz, 12: 927-937, DOI: 10.18668/NG.2018.12.07.

Kremieniewski M., 2019. O konieczności prowadzenia serwisowych badań parametrów technologicznych zaczynów uszczelniających. Nafta-Gaz, 1: 48-55. DOI:0.18668/NG.2019.01.07.

Kremieniewski M., Rzepka M., 2016a. Przyczyny i skutki przepływu gazu w zacementowanej przestrzeni pierścieniowej otworu wiertniczego oraz metody zapobiegania temu zjawisku. Nafta-Gaz, 9: 722-728. DOI: 10.18668/NG.2016.09.06

Kremieniewski M., Rzepka M., 2016b. Korelacja parametrów charakteryzujących strukturę porową kamieni cementowych badanych za pomocą porozymetrii rtęciowej oraz mikrotomografii komputerowej. Nafta-Gaz, 12: 1076-1083. DOI 10.18668/ NG.2016.12.10.
Kremieniewski M., Rzepka M., 2017. Celowość prowadzenia prac badawczych nad nowymi środkami obniżającymi filtrację zaczynów cementowych. Nafta-Gaz, 8: 583-590. DOI: 10.18668/ NG.2017.08.05.

Kremieniewski M., Rzepka M., 2018. Poprawa szczelności płaszcza cementowego za pomocą innowacyjnych dodatków antymigracyjnych. Nafta-Gaz, 6: 8-15. DOI: 10.18668/NG.2018.06.06

Kremieniewski M., Rzepka M., Stryczek S., Wiśniowski R., Kotwica Ł., Złotkowski A., 2015: Korelacja przepuszczalności i parametrów opisujących strukturę stwardniałych zaczynów cementowych stosowanych do uszczelniania otworów w rejonie Basenu Pomorskiego. Nafta-Gaz, 10: 737-746. DOI: 10.18668/ NG2015.10.04.

Kudowski W., 2010. Chemia cementu i betonu. Warszawa: Wydawnictwo Naukowe PWN.

Nelson E.B. (ed.), 1990. Well Cementing. Schlumberger Educational Services, Houston, Teksas, USA.

Radecki S., Witek W., 1999. Zapobieganie migracji gazu. Dobór technik i technologii cementowania. Nafta-Gaz, 5: 263-272.

Rzepka M., Kremieniewski M., Dębińska E., 2012. Zaczyny cementowe przeznaczone do uszczelniania eksploatacyjnych kolumn rur okładzinowych na Niżu Polskim. Nafta-Gaz, 8: 512-522.

Rzepka M., Stryczek S., 2008. Laboratoryjne metody określania parametrów technologicznych świeżych zaczynów uszczelniających przed zabiegiem związanym z procesem uszczelniania kolumn rur okładzinowych w otworach wiertniczych. Wiertnictwo, Nafta-Gaz, 25/2: 625-636.

Stryczek S. (red.), Wiśniowski R., Uliasz-Misiak B., Złotkowski A., Kotwica Ł., Rzepka M., Kremieniewski M., 2016. Studia nad doborem zaczynów uszczelniających w warunkach wierceń w Basenie Pomorskim. Monografia pod redakcją Stryczka S. Wydawnictwa AGH, Kraków.

Stryczek S., Wiśniowski R., Gonet A., Ferens W., 2009. Parametry reologiczne świeżych zaczynów uszczelniających w zależności od czasu ich sporządzania. Wiertnictwo, Nafta, Gaz, 26(1-2): 369-382.

Stryczek S., Wiśniowski R., Gonet A., Złotkowski A., 2014. The influence of time of rheological parameters of fresh cement slurries. AGH Drilling, Oil, Gas, 31(1): 123-133.

Wiśniowski R., Stryczek S., Skrzypaszek K. 2007: Kierunki rozwoju badań nad reologią płynów wiertniczych. Wiertnictwo, Nafta, Gaz 24: 595-607.

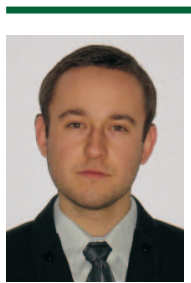

Dr inż. Marcin KREMIENIEWSKI

Adiunkt w Zakładzie Technologii Wiercenia Instytut Nafty i Gazu - Państwowy Instytut Badawczy ul. Lubicz 25 A

31-503 Kraków

E-mail: marcin.kremieniewski@inig.pl 